\title{
Analisis Faktor-Faktor yang Memengaruhi Terjadinya Turnover Karyawan pada PT X
}

\author{
Raden Irwan Priambodo \\ Magister Manajemen, Unversitas Airlangga \\ e-mail: irwan.priambodo@yahoo.com
}

\begin{abstract}
One form of behavior is the wish of employees the move (turnover intentions) that led to the decision employees to left his job. With the level of turnover to companies, will increase have a potential costs, whether it is the cost of training who have invested on employees, the performance that should be sacrificed, and the costs recruitment and training back. The purpose of this research is to know the factors that affect turnover employee who happened to PT X. This study used a quantitative approach. Quantitative the kind of research that is used on the thesis this is quantitative explorative. The population of this study is all former employees of PT X total of 145 employees. The sample used using formulas slovin which totaled 107 an employee with a method of purposive addition to random. Data collection method that is used is questionnaire and documentation The result of this research are six factors that becomes consideration respondents to get out of companies are compensation (factor of 1), career opportunity (factor of 2), employee opportunities elsewhere (factor of 3), personal growth and development (factors of 4), uncomfortable work (factor of 5) and job dissatisfaction (factor of 6).
\end{abstract}

Kata Kunci: turnover intention, factor analysis

\section{PENDAHULUAN}

Sumber daya manusia dipandang sebagai asset perusahaan yang penting, karena manusia merupakan sumber daya yang dinamis dan selalu dibutuhkan dalam tiap proses produksi barang dan jasa. Di dalam perusahaan, sumber daya manusia merupakan sustainable competitive advantage. Di mana produk yang dimiliki perusahaan dapat dengan mudah ditiru oleh kompetitor, sedangkan kualitas sumber daya manusia yang dimiliki perusahaan, tidak akan pernah bisa sama. Oleh karena itu perusahaan dituntut tidak hanya dapat merekrut karyawan yang berkualitas, namun juga mempertahankan karyawannya (Sexton et al., 2004).

Kompas Cyber Media (2007) merilis hasil survei Global Strategic Rewards 2007/2008 yang dilakukan Watson Wyatt yang menemukan bahwa turnover karyawan saat ini telah menjadi masalah perusahaan-perusahaan di Indonesia, karena yang sering terjadi adalah karyawan berprestasi tinggilah yang gampang berpindah perusahaan. Hal ini memberikan dampak yang buruk pada perusahaan karena karyawan berprestasi tinggi bukanlah hal yang mudah didapat.

Salah satu bentuk perilaku karyawan tersebut adalah keinginan berpindah (turnover intentions) yang berujung pada keputusan karyawan untuk meninggalkan pekerjaannya. Dengan tingginya tingkat turnover pada perusahaan, akan semakin banyak menimbulkan berbagai potensi biaya, baik itu biaya pelatihan yang sudah diinvestasikan pada karyawan, tingkat kinerja yang mesti dikorbankan, maupun biaya rekrutmen dan pelatihan kembali (Suwandi dan Indriantoro 1999).

Menurut laporan dari Tower Watson, menyebutkan tingkat voluntary turnover di Indonesia mencapai 20,35 persen di atas dari tingkat voluntary turnover yang terjadi di negara 


\begin{tabular}{lccc} 
All employee categories & Global & $\begin{array}{c}\text { Fast-growing } \\
\text { Asia-Pacific countries }\end{array}$ & Indonesia \\
\hline Voluntary & $\%$ & $\%$ & $\%$ \\
Involuntary & 8.24 & 12.39 & 20.35 \\
Total & 2.96 & 2.61 & 0.52 \\
\hline
\end{tabular}

Gambar 1

Sumber: 2012-2013 Global Talent Management and Rewards Study', Towers Watson, 2012

berkembang di Asia Pasifik (12,39 persen) dan tingkat voluntary turnover di dunia yang mencapai angka 8,24 persen. Sedangkan untuk tingkat involuntary turnover di Indonesia mencapai 0,52 persen, di bawah rata-rata negara berkembang di Asia Pasifik yang mencapai 2,61 persen dan rata-rata dunia yang mencapai 2,69 persen. Namun, jika diukur seluruhnya tingkat employee turnover di Indonesia mencapai 20,87 persen, sedangkan negara berkembang di Asia Pasifik rata-rata hanya 15 persen dan rata-rata dunia 11,20 persen.

PT "X" merupakan salah satu perusahaan yang bergerak di bidang satu perusahaan yang sedang berkembang dan bergerak di bidang pelayanan jasa laboratorium kesehatan. PT " $X$ " mempunyai 18 cabang yang tersebar di seluruh Indonesia. Turnover karyawan juga terjadi pada PT "X", menurut data departemen SDM menunjukkan adanya tren turnover karyawan. Data pada tahun 2014 hingga 2015 menunjukkan adanya peningkatan turnover karyawan dari 48,1 persen menjadi 112,1 persen.

Dalam Grafik 1 menunjukkan adanya tren penurunan tingkat turnover pada karyawan yang berstatus karyawan tetap, pada tahun 2014 sebesar 31\% hingga pada tahun 2016 sebesar 12,9\%. Sedangkan tingkat turnover untuk karyawan yang berstatus kontrak mengalami tren kenaikan, pada tahun 2014 sebesar 31\%, tahun 2015 sebesar 52,9\% dan pada tahun 2016 sebesar $58,1 \%$. Untuk karyawan dengan status training, tingkat turnover pada tahun 2014 mencapai $37,9 \%$, mengalami penurunan menjadi $17,6 \%$ pada tahun 2015 dan kembali meningkat menjadi 29\% pada tahun 2016.

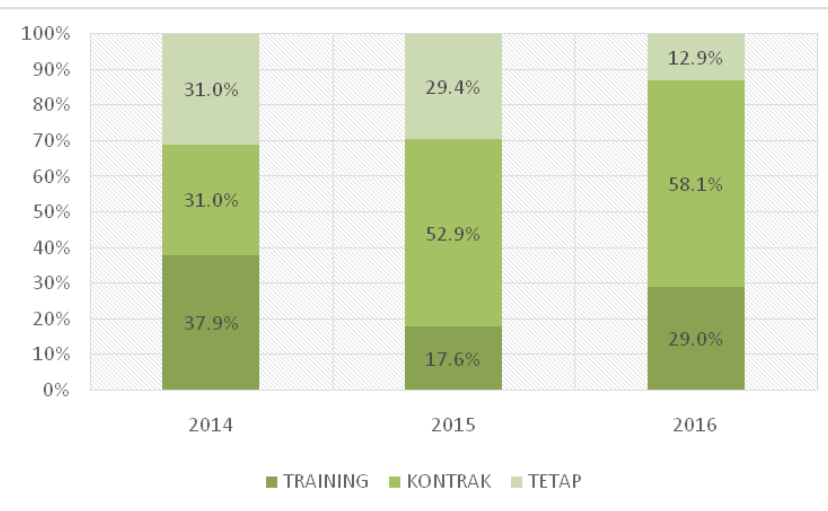

Grafik 1 Employee Turnover Rate PT "X” Berdasarkan Status Kerja Periode 2014-2016

Sumber: Data internal departemen SDI \& Umum PT "X"

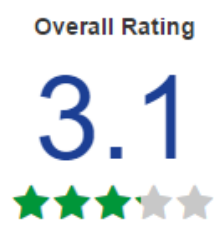

Sumber: www.jobstreet.co.id, 2017.

\begin{tabular}{|c|c|c|c|c|}
\hline Benefits \& perks & Career development & Work/life balance & Working environment & Management \\
\hline 2.2 & 2.0 & 3.2 & 4.0 & 1.8 \\
\hline 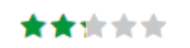 & 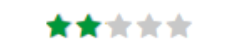 & $\star \star \star \star t \downarrow t$ & $\star \star \star \star \star \star t$ & $\star \star \Delta t \Delta$ \\
\hline
\end{tabular}

Gambar 2 
Berdasarkan informasi yang dihimpun dari Jobstreet.co.id, review dari PT "X" yang dilakukan oleh mantan karyawan menunjukkan overall rating pada angka 3,1 dari 5. Pada review ini ada lima aspek yang dinilai yaitu benefit \& perks, career development, work life balance, working environment, dan management. Dari penjabaran review pada gambar I.2 ada tiga aspek yang memiliki skor rendah, yaitu management dengan skor 1,8, career development dengan skor 2,0 dan benefit \& perks dengan skor 2,2. Sedangkan dua aspek yang mendapat penilaian tertinggi adalah work life balance dengan skor 3,2, dan working environment dengan skor 4 .

\section{PERUMUSAN MASALAH}

Berdasarkan uraian latar belakang permasalahan di dalam penelitian, maka pertanyaan penelitian yang akan dijawab melalui penelitian ini adalah: "Analisis faktor-faktor yang memengaruhi terjadinya turnover karyawan pada PT "X"?"

\section{TINJAUAN PUSTAKA}

\section{Turnover}

Keluarnya pekerja dari perusahaan atau organisasi tampaknya menimbulkan biaya yang sangat besar bagi organisasi (Arthur, 2001). Proses rekrutmen tidak hanya membutuhkan waktu, tetapi juga tenaga dan biaya yang tidak sedikit. Untuk itu memang diperlukan suatu usaha dari perusahaan untuk mempertahankan karyawan terutama jika mereka merupakan menempati posisi strategis dalam perusahaan.

Menurut Noe (2000), turnover adalah salah satu bentuk dari physical job withdrawal, sedangkan yang dimaksud dengan job withdrawal adalah adanya satu set perilaku ketidakpuasan atas pekerjaan, yang membuat seseorang menghindari situasi pekerjaan. Menghindari situasi pekerja bisa diekspresikan dalam bentuk penolakan secara fisik, artinya pekerja itu benar-benar keluar dari tempat kerjanya. Bisa pula ekspresi itu berbentuk produktivitas kerja yang rendah, namun pekerja tersebut belum pindah dari tempat kerjanya. Bentuk job withdrawal yang lain adalah berbentuk sikap protes dari pekerja, namun kelak arahnya adalah pekerja tersebut akan keluar meninggalkan organisasi atau perusahaan, ini juga merupakan salah satu definisi turnover (Noe, 2000).

\section{Jenis-Jenis Employee Turnover}

Menurut Robert L. Mathis dan John H. Jackson (2008, p84-86), employee turnover dikelompokan dalam beberapa cara yang berbeda. Setiap klasifikasi berikut dapat digunakan dan tidak terpisah satu sama lain.

\section{Voluntary Turnover}

Voluntary turnover merupakan turnover yang diajukan oleh perorangan adalah turnover sukarela. Turnover secara sukarela dapat disebabkan oleh banyak faktor, termasuk peluang karier, gaji, pengawasan, geografi, dan alasan pribadi atau keluarga. Turnover secara sukarela juga tambah meningkat seiring dengan bertambahnya ukuran organisasi, hal ini dikarenakan semakin besar ukuran perusahaan, sehingga semakin banyak kemungkinan terjadinya turnover. Semakin perusahaan tersebut bersifat impersonal, begitu pula dengan birokrasi organisasi yang ada dalam perusahaan tersebut.

\section{Involuntary Turnover}

Involuntary turnover merupakan pergerakan keluar masuknya seorang individu dari suatu 
organisasi, yang dilakukan bukan atas kehendak individu. Nama lain tipe ini adalah involuntary separation, yang berarti berhentinya seseorang dari organisasi atas keinginan organisasi, termasuk kematian, dan diperintahkan mengundurkan diri. Involuntary turnover diajukan oleh pihak organisasi di mana karyawan bekerja. Salah satu contoh situasi di mana seseorang diperintahkan untuk mengundurkan diri atau bukan atas keinginan antara lain PHK (pemutusan hubungan kerja) karena perusahaan tempat bekerja mengalami kebangkrutan atau karena kinerja karyawan rendah.

Menurut Heneman dan Judge (2009, dalam Iqbal, 2010), involuntary turnover dapat dibedakan menjadi dua kategori berikut.

1. Discharge Turnover, yaitu turnover karyawan yang disebabkan oleh tindakan indisipliner atau kinerja yang kurang memuaskan.

2. Downsizing Turnover, yaitu turnover karyawan yang disebabkan adanya restrukturisasi organisasi, program pengurangan karyawan dalam meningkatkan performa perusahaan dan meningkatkan nilai bagi para pemegang saham.

\section{Proses Employee Turnover}

Evaluate Standing with Current Job merepresentasikan proses evaluasi pekerjaan saat ini, sedangkan Determine Job Satisfaction or Dissatisfaction merepresentasikan hasil emosional dari kepuasan atau ketidakpuasan kerja. Beberapa studi tentang turnover menguji hubungan langsung antara kepuasan kerja dengan turnover. Think of quitting menjelaskan bahwa salah satu dari konsekuensi ketidakpuasan kerja adalah dorongan berpikir untuk keluar dari pekerjaan. Bentuk lain dari pengunduran diri yaitu absenteeism (banyaknya ketidakhadiran) dan passive job behavior (tidak berkerja dengan giat).
Evaluate the Idea of Searching of New Job memberikan gambaran bahwa berikut merupakan evaluasi dari kebutuhan yang diharapkan dari proses pengunduran diri. Jika karyawan merasa bahwa biaya yang dikeluarkan untuk keluar dari suatu pekerjaan adalah rendah, maka hal ini akan memperkuat keinginan karyawan untuk keluar, sebaliknya jika karyawan merasa biaya yang dikeluarkan tinggi maka karyawan akan mempertimbangkan kembali pekerjaan yang sekarang dan menekan keinginan untuk keluar. Biaya yang dimaksud adalah biaya perjalanan, kehilangan waktu kerja, juga kehilangan kesenioritasan dan lainnya. Jika kesempatan untuk mendapatkan pekerjaan baru tersedia dan biaya yang diperlukan tidak menjadi penghalang, maka tahap selanjutnya adalah Plan the Search for The New Job yaitu perilaku untuk mencari pekerjaan lainnya. Pada tahap ini faktor yang tidak berhubungan dengan pekerjaan bisa juga mendatangkan keinginan untuk mencari pekerja lain. Faktor tersebut contohnya adalah kesehatan, kepindahan suami/istri dan lain sebagainya. Keinginan untuk mencari pekerjaan baru tersebut, ditunjukkan pada tahap actually do the Search. Langkah selanjutnya adalah Evaluate the Alternatives yaitu karyawan mulai melakukan berbagai evaluasi untuk alternatif yang ada dengan pekerjaan saat ini yang digambarkan pada tahap Compare Alternatives to Current Job. Apabila dari hasil membandingkan tersebut didapatkan alternatif pekerjaan yang lebih baik, maka hal tersebut akan menjadi pendorong karyawan untuk keluar dari pekerjaan yang ditunjukkan pada tahap Plan To Quit or Stay. Keinginan tersebut diwujudkan dalam tahap Actually Quit or Stay. Namun jika hasil evaluasi menunjukkan sebaliknya yaitu pekerjaan saat ini lebih baik daripada alternatif pekerjaan lainnya, maka karyawan akan melanjutkan pencarian, meng- 
evaluasi ulang apa yang diharapkan dari pengunduran diri, evaluasi pekerjaan saat ini, menerima pekerjaan saat ini, mengurangi keinginan untuk keluar dari pekerjaan saat ini dan atau menggunakan cara pengunduran diri lainnya.

\section{Dampak Employee Turnover}

Berbagai sumber menyebutkan bahwa employee turnover dapat memberikan dampak negatif atau positif. Menurut Butali et al., 2013, employee turnover memberikan beberapa dampak negatif, di antaranya adanya penurunan atas kepuasan konsumen terhadap kinerja organisasi, menurunkan kemampuan organisasi dalam menciptakan profit, dan menurunkan moral karyawan.

Sedangkan menurut penelitian Apomah dan Cudjor (2015), employee turnover bisa memberikan dampak positif dan negatif bagi organisasi. Untuk dampak positif dari employee turnover di antaranya, memberikan kesempatan promosi bagi karyawan yang bertahan, memberikan adanya ide, inovasi, dan skill yang baru ke dalam organisasi, menggantikan karyawan yang memiliki performa rendah.

\section{METODE PENELITIAN}

Penelitian ini menggunakan pendekatan kuantitatif. Jenis penelitian kuantitatif yang digunakan pada tesis ini adalah kuantitatif eksploratif, menurut Sekaran (2013), penelitian eksploratif dilakukan jika informasi dari suatu keadaan atau fenomena tidak diketahui dengan pasti, sehingga perlu digali informasi yang lebih dalam dengan bantuan literatur ataupun membentuk diskusi atau wawancara dengan objek penelitian. Pendekatan ini dimulai dengan teori-teori, langkah selanjutnya adalah membuat model analisis, mengidentifikasikan variabel, membuat definisi operasional, mengumpulkan data populasi dan sampel serta melakukan analisis. Penelitian ini menggunakan teknik analisis faktor.

\section{Sampel dan Teknik Pengambilan Sampel}

Populasi dan sampel dalam penelitian ini merupakan seluruh mantan karyawan PT "X". Jumlah populasi dalam penelitian ini sebanyak 145 orang. Di dalam penelitian ini teknik pengambilan sampel yang digunakan adalah purposive random sampling, sedangkan jumlah sampel yang diambil berdasarkan rumus slovin sebanyak 107 orang.

\section{Lokasi Penelitian}

Penelitian ini dilakukan di PT X.

\section{Teknik Analisis}

Analisis faktor adalah teknik yang digunakan untuk menganalisis struktur dengan hubungan antara variabel-variabel dengan jumlah yang besar, misalnya hasil tes, bentuk tes, respons dari angket, angket dan lainnya, analisis tersebut dilakukan dengan cara menentukan variabelvariabel yang paling saling berhubungan/faktor. Fungsi umum dari analisis faktor ialah untuk menemukan cara dalam merangkum informasi dalam bentuk faktor-faktor (variabel-variabel) menjadi faktor yang lebih kecil tanpa mengurangi informasi yang sudah dikumpulkan (Hairs, et al, 2006:102).

\section{ANALISIS DAN PEMBAHASAN HASIL PENE- LITIAN}

\section{Uji Validitas dan Reliabilitas}

Uji validitas dilakukan pada kuesioner yang dibagikan kepada responden, yaitu dengan 
melihat 26 variabel yang sudah mengalami proses extraction pada tabel communalities. Karena faktor loading pada tabel communalities hasilnya $>0.4$ maka 26 variabel pada kuesioner tersebut dinyatakan valid.

\begin{tabular}{|c|c|}
\hline & Extraction \\
\hline x1 & 0.508 \\
x2 & 0.610 \\
x3 & 0.724 \\
x4 & 0.637 \\
x5 & 0.745 \\
x6 & 0.659 \\
x7 & 0.782 \\
x8 & 0.664 \\
x9 & 0.742 \\
x10 & 0.662 \\
x11 & 0.682 \\
x12 & 0.649 \\
x13 & 0.677 \\
x14 & 0.454 \\
x15 & 0.597 \\
x16 & 0.496 \\
x17 & 0.690 \\
x18 & 0.718 \\
x19 & 0.741 \\
x20 & 0.583 \\
x21 & 0.708 \\
x22 & 0.673 \\
x23 & 0.745 \\
x24 & 0.780 \\
x25 & 0.763 \\
x26 & 0.623 \\
\hline
\end{tabular}

Uji reliabilitas pada penelitian ini menggunakan besaran Cronbach's Alpha yang lebih besar dari 0.6 yaitu 0.921 sehingga dapat dikatakan reliabel.

\section{Analisis Faktor}

Analisis faktor dilakukan untuk mencari faktor-faktor baru dari 26 variabel dilihat dari tingkat kepentingannya agar dapat dianalisis lebih lanjut. Digunakan metode analisis faktor karena peneliti ingin menganalisis faktor penting yang menjadi pertimbangan karyawan terhadap keinginan keluar dari perusahaan. Tahapan analisis faktor terdiri dari dua tahap yaitu KMO dan Bartlett's Test serta extraction.

KMO dan Barlett

\begin{tabular}{|l|l|}
\hline Kaiser-Meyer-Olkin Measure of Sampling Adequacy & 0.847 \\
\hline Bartlett's Test of Sphericity (sig) & 0.000 \\
\hline
\end{tabular}

Pengajuan KMO and Bertlett's Test dilakukan guna melihat variabel dan sampel yang diambil sudah cukup untuk dilakukan analisis. Dari hasil penelitian ditemukan angka 0.847 dengan tingkat signifikansi 0.000 . Hasil KMO and Barlett's Test sudah di atas 0.5 dan tingkat signifikansi sudah di bawah 0.05 , sehingga dapat dilakukan tahapan selanjutnya yaitu proses $e x$ traction (Hair, 2010).

Adanya Anti-image Matrices digunakan untuk melihat kelayakan setiap variabel saat dilakukan analisis faktor. Adanya huruf "a" pada beberapa angka dengan bentukan garis diagonal pada setiap variabel mengartikan besaran MSA (Measure of Sampling Adequacy) variabel dengan syarat lebih besar dari 0.5 (Hair, 2006) sehingga dapat disimpulkan bahwa semua variabel layak untuk dianalisis.

\section{Extraction, Communalities, Variance Explained}

Communalities merupakan proses pertama dari extraction yang fungsinya untuk mengetahui seberapa erat hubungan pernyataan dengan faktor-faktor yang terbentuk. Kolom extraction menunjukkan seberapa besar faktor yang akan terbentuk dapat menjelaskan varian dari suatu faktor, sehingga semakin besar nilai communalities maka semakin erat hubungan nya dengan faktor yang terbentuk.

Total variance explained berfungsi untuk mengekstrak sejumlah variabel menjadi beberapa faktor baru. Dari 26 variabel diekstraksi menjadi enam faktor dengan melihat nilai eigenvalue, di mana memiliki syarat lebih dari 1 (Hair, 2006). 
Total Variance Explained

\begin{tabular}{|c|c|c|c|c|c|c|c|c|c|}
\hline \multirow{2}{*}{ Component } & \multicolumn{3}{|c|}{ Initial Eigenvalues } & \multicolumn{3}{|c|}{$\begin{array}{c}\text { Extraction Sums of Squared } \\
\text { Loadings }\end{array}$} & \multicolumn{3}{|c|}{$\begin{array}{c}\text { Rotation Sums of Squared } \\
\text { Loadings }\end{array}$} \\
\hline & Total & $\begin{array}{c}\% \text { of } \\
\text { Variance } \\
\end{array}$ & $\begin{array}{c}\text { Cumulative } \\
\% \\
\end{array}$ & Total & $\begin{array}{c}\% \text { of } \\
\text { Variance } \\
\end{array}$ & $\begin{array}{c}\text { Cumulative } \\
\% \\
\end{array}$ & Total & $\begin{array}{c}\% \text { of } \\
\text { Variance } \\
\end{array}$ & $\begin{array}{c}\text { Cumulative } \\
\%\end{array}$ \\
\hline 1 & 9.409 & 36.189 & 36.189 & 9.409 & 36.189 & 36.189 & 5.066 & 19.486 & 19.486 \\
\hline 2 & 2.581 & 9.927 & 46.116 & 2.581 & 9.927 & 46.116 & 2.848 & 10.953 & 30.440 \\
\hline 3 & 1.621 & 6.236 & 52.352 & 1.621 & 6.236 & 52.352 & 2.840 & 10.924 & 41.364 \\
\hline 4 & 1.424 & 5.476 & 57.828 & 1.424 & 5.476 & 57.828 & 2.419 & 9.302 & 50.667 \\
\hline 5 & 1.205 & 4.634 & 62.462 & 1.205 & 4.634 & 62.462 & 2.181 & 8.390 & 59.057 \\
\hline 6 & 1.072 & 4.122 & 66.582 & 1.072 & 4.122 & 66.582 & 1.957 & 7.528 & 66.584 \\
\hline
\end{tabular}

Component Matrix, Rotated Component Matrix dan Structure Matrix

Component Matrix memuat koefisien yang digunakan untuk menyatakan variabel standar yang disebut faktor dari delapan faktor baru yang terbentuk. Koefisien faktor loading menerangkan korelasi antara variabel asal dengan faktornya. Nilai korelasi yang besar menyatakan hubungan yang erat antara faktor variabel asal sehingga variabel dapat digunakan untuk membentuk faktor. Untuk mempermudah interpretasi maka Component Matrix dirotasi dengan metode rotasi orthogonal atau rotasi oblique.

\section{Metode Rotasi Orthogonal (Varimax)}

Hasil dari metode rotasi orthogonal dapat dilihat pada kolom rotated component matrix di bawah ini, faktor baru yang dipilih adalah faktor yang memiliki faktor loading $>0.6$, dengan pertimbangan practical significance bukan statistical significance (Hair, 2010:117) sehingga didapatkan 17 variabel baru.

\begin{tabular}{|l|l|l|l|l|l|l|}
\hline & \multicolumn{7}{|c|}{ Component } \\
\cline { 2 - 7 } & 1 & 2 & 3 & 4 & 5 & 6 \\
\hline x24 & .871 & & & & & \\
x23 & .816 & & & & & \\
x25 & .801 & & & & & \\
x22 & .781 & & & & & \\
x21 & .649 & & & & & \\
x15 & .603 & & & & & \\
x19 & & .747 & & & & \\
x20 & & .725 & & & & \\
x18 & & .723 & & & & \\
x13 & & & .725 & & & \\
x26 & & & .659 & & & \\
x3 & & & & .792 & & \\
x7 & & & & .761 & & \\
x9 & & & & & & \\
x8 & & & & & & \\
x5 & & & & & & \\
x6 & & & & & & \\
\hline
\end{tabular}




\begin{tabular}{|c|c|}
\hline Faktor Baru & Variabel \\
\hline \multirow{6}{*}{$\begin{array}{c}1 \\
\text { Compensation }\end{array}$} & X.24Sedikitnya peningkatan nilai gaji yang diterima \\
\hline & X.23Ketidakadilan dalam sistem penggajian \\
\hline & X.25 Sedikit kesempatan untuk mengeluarkan ide atau gagasan \\
\hline & X.22 Sedikitnya peluang untuk mencapai posisi yang lebih tinggi \\
\hline & X.21Gaji yang diterima cukup kecil \\
\hline & X.15Sedikit kesempatan untuk menjadi karyawan tetap \\
\hline \multirow{3}{*}{$\begin{array}{c}2 \\
\text { Career Opportunity }\end{array}$} & X.19Tidak adanya kontrak kerja \\
\hline & X.20Sistem promosi yang berjalan lambat \\
\hline & X.18 Adanya ketidakpastian akan pekerjaan di masa depan \\
\hline \multirow{2}{*}{$\begin{array}{c}3 \\
\text { Employee Opportunities Elsewhere }\end{array}$} & X. 13Adanya tawaran pekerjaan dengan gaji yang lebih baik \\
\hline & X.26Adanya peluang kerja pada perusahaan lain \\
\hline \multirow{2}{*}{$\begin{array}{c}4 \\
\text { Personal Growth and Development }\end{array}$} & X.3Stress kerja yang cukup tinggi \\
\hline & X.7Tidak adanya training yang memadai \\
\hline \multirow{2}{*}{$\begin{array}{c}5 \\
\text { Uncomfortable Work }\end{array}$} & X.9Kembali ke dunia pendidikan \\
\hline & X.8Tidak berminat dengan pekerjaan saat ini \\
\hline \multirow{2}{*}{$\begin{array}{c}6 \\
\text { Job Dissatisfaction }\end{array}$} & X.5Tidak ada komunikasi yang terbuka \\
\hline & X.6Ketidakpuasan atas kebijakan perusahaan \\
\hline
\end{tabular}

Karena hasil rotasi orthogonal menciptakan variabel yang lebih banyak dan sesuai serta adanya kesinambungan yang terbentuk pada hasil analisis faktor, maka peneliti menggunakan hasil analisis dari rotasi orthogonal daripada rotasi oblique. Tabel di atas merupakan penjabaran hasil analisis dan nama faktor baru yang telah dibentuk.

\section{SIMPULAN DAN SARAN}

\section{Simpulan}

Dari hasil penelitian, dan analisis pembahasan tentang faktor-faktor yang menjadi pertimbangan responden terhadap keinginan untuk keluar dari perusahaan, maka dapat disimpulkan bahwa terdapat enam faktor yang menjadi pertimbangan responden terhadap keinginan untuk keluar dari perusahaan.

\section{Faktor I: Compensation}

a. Sedikitnya peningkatan nilai gaji yang diterima $\left(\mathrm{X}_{24}\right)$

b. Ketidakadilan dalam sistem penggajian $\left(\mathrm{X}_{23}\right)$ c. Sedikit kesempatan untuk mengeluarkan ide atau gagasan $\left(\mathrm{X}_{25}\right)$

d. Sedikit peluang untuk mencapai posisi yang lebih tinggi $\left(\mathrm{X}_{22}\right)$

e. Gaji yang diterima cukup kecil $\left(\mathrm{X}_{21}\right)$

f. Sedikit kesempatan untuk menjadi karyawan tetap $\left(\mathrm{X}_{15}\right)$

2. Faktor II: Career Opportunity

a. Tidak adanya kontrak kerja yang jelas $\left(\mathrm{X}_{19}\right)$

b. Sistem promosi yang berjalan lambat $\left(\mathrm{X}_{20}\right)$

c. Adanya ketidakpastian pekerjaan di masa depan $\left(\mathrm{X}_{18}\right)$

3. Faktor III: Employee Opportunities Elsewhere

a. Adanya tawaran pekerjaan dengan gaji yang lebih baik $\left(\mathrm{X}_{13}\right)$

b. Adanya peluang kerja pada perusahaan lain $\left(\mathrm{X}_{26}\right)$

4. Faktor IV: Personal Growth and Development

a. Stress kerja yang cukup tinggi $\left(\mathrm{X}_{3}\right)$

b. Tidak adanya training yang memadai $\left(\mathrm{X}_{7}\right)$

5. Faktor V: Uncomfortable Work

a. Kembali ke dunia pendidikan $\left(\mathrm{X}_{9}\right)$ 
b. Tidak berminat dengan pekerjaan saat ini $\left(\mathrm{X}_{8}\right)$

6. Faktor VI: Job Dissatisfaction

a. Tidak ada komunikasi yang terbuka $\left(\mathrm{X}_{5}\right)$

b. Ketidakpuasan atas kebijakan perusahaan $\left(\mathrm{X}_{6}\right)$

\section{Saran}

Saran yang dihasilkan adalah sebagai berikut.

\section{Faktor I: Compensation}

Dalam hal ini PT "X" disarankan untuk melakukan job evaluation dan melakukan salary survey secara berkala agar tercipta sistem remunerasi mencapai internal equality dan market competitiveness.

Selain itu, PT “X” diharapkan dapat memberikan kesempatan kepada karyawan melalui proses rekrutmen internal, sehingga dapat memberikan motivasi kerja dan menjaga kesetiaan karyawan terhadap perusahaan.

\section{Faktor II: Career Opportunity}

PT "X" disarankan untuk mulai menyusun perencanaan program pengembangan karier. Perencanaan program pengembangan karier, dapat dimulai dengan mengembangkan peta kompetensi yang ada dalam perusahaan untuk kemudian dilakukan proses perumusan level kompetensi yang ada. Tahapan proses inilah yang kemudian ditetapkan sebagai peta kompetensi yang ada dalam perusahaan. Pengembangan dan pengelompokan ini kemudian harus disesuaikan dengan karakteristik dari pekerjaan yang ada dalam jabatan tersebut. Proses analisis jalur karier dengan mengikuti pola kompetensi per jabatan. Dari tahapan ini, dapat dilakukan proses pemetaan konsep seleksi dan metode evaluasi yang tepat dan dilaksanakan secara objektif sebagai bentuk gambaran dari pengembangan jalur karier yang ditetapkan dalam perusahaan.

\section{Faktor III: Employee Opportunities Else- where}

Melakukan pengembangan retention program untuk mengurangi terjadinya voluntary turnover pada karyawan. Terutama pada karyawan yang memiliki kualifikasi tertentu dan memiliki kinerja yang baik di perusahaan.

\section{Faktor IV: Personal Growth and Develop- ment}

Melakukan kegiatan olah raga yang melibatkan seluruh karyawan, misalnya futsal dan badminton yang dapat dilakukan secara berkala dua minggu sekali sehingga menjaga kebugaran, meningkatkan keakraban antar karyawan dan dapat mengurangi stress akibat bekerja.

Mengadakan liburan bersama dengan melibatkan karyawan beserta anggota keluarganya.

Meningkatkan program siraman rohani pada karyawan, yang disesuaikan dengan agama dan kepercayaan yang dianut oleh karyawan.

Memberikan training secara berkala pada karyawan sesuai dengan skill dan kompetensi yang dibutuhkan.

\section{Faktor V: Uncomfortable Work}

Memberikan pos jabatan sesuai dengan latar belakang pendidikan. Hal ini dapat meningkatkan motivasi dan semangat karyawan dalam bekerja. Namun harus ditunjang dengan lingkungan pekerjaan yang nyaman. 


\section{Faktor VI: Job Dissatisfaction}

Menciptakan komunikasi yang terbuka dengan karyawan sehingga dapat meningkatkan kepercayaan dari karyawan sehingga karyawan dapat memberikan sumbangsih pemikiran demi kemajuan perusahaan. Perusahaan diharapkan lebih terbuka terkait penerapan suatu kebijakan terhadap karyawan.

\section{DAFTAR KEPUSTAKAAN}

Allen, D.G., Bryant, P.C., \& Vandaman, J.M. 2010. Retaining talent: Replacing misconceptions with evidence-based strategies. Academy of Management Perspectives, Vol. 24(2): 48-64.

Ampomah, Philipina dan Cudjor, Samuel K. 2015. The Effect of Employee Turnover on Organizations (Case Study of Electricity Company of Ghana, Cape Coast). Asian Journal of Social Sciences and Management Studies, 2(1): 21-24.

Armstrong, Michael and Baron, Angela. 2013. Human Capital Management: Concept and Implementation. Jakarta: Penerbit PPM.

Arthur, Diane. 2001. The Employee Recruitment and Retention Handbook. New York: Amacon.

Butali, Namasaka David et al. 2013. Effects of Staff Turnover on the Employee Performance of Work at Masinde Muliro University of Science and Technology. International Journal of Human Resource Studies, Vol. 3, No. 1.

Booth, Simon dan Hamer, Kristian. 2007. Labour Turnover in The Retail Industry: Predicting The Role of Individual Organizational dan Environmental Factors. International Journal of Retail \& Distribution Management, Vol. 35 (4): 289-307.
Branham L. 2005. How to Recognize the Subtle signs and Act before it's Too Late: The 7 Hidden Reasons Employees Leave. Executive Book Summaries, 27 (6).

Compdata Survey. 2017: 2016 Turnover Rates by Industry. http://www.compensationforce.com/2017/04/2016-turnover-ratesby-industry.html. Diakses pada tanggal 14 Juni 2017.

Groh, Alexander P. dan Which, Matthias. A Composite Measure to Determine a Host Country's Attractiveness for Foreign Direct Investment. Working Paper. University of Navarra Business School.

Hair, Joseph F. et al. 2006 Multivariate Data Analysis, Edisi keenam. New Jersey: Pearson Education.

Hair, Joseph F. et al. 2010. Multivariate Data Analysis. Edisi ketujuh. New Jersey: Pearson Prentice Hall.

Hasibuan, Malayu. 2012. Manajemen Sumber Daya Manusia, Cetakan keenam belas. Jakarta: Bumi Aksara.

Hollenbeck, Jr., \& Williams, C.R. 1986. Turnover Functionality versus Turnover Frequency: a Note on Work Attitudes and Organizational Effectiveness. Journal of Applied Psychology, (71): 601-611.

Ibrahim, Adika M. 2013. Analisis Penyebab Terjadinya Turnover Pegawai pada Bank X - Unit Kerja Y. Tesis S2. Universitas Airlangga.

Jewell, L.N. dan Siegall, Marc. 1998. Psikologi Industri/Organisasi Modern. Jakarta: Arcan.

Jobstreet Company Review. 2017. PT "X” Rating \& Review. https://www.jobstreet.co.id/ en/companies/778965-pt-x/reviews Diakses pada tanggal 18 April 2017.

Kompas Cyber Media. 2007: Karyawan Berprestasi Tinggi Gampang Pindah. http:// 
www2.kompas.com/ver1/Perempuan/0712/ 12/201434.htm Diakses pada tanggal 20 Juli 2016.

Mathis, Robert L and Jackson, John H. 2008. Human Resource Management. 12th ed. Cincinnati: South-Western Publishing.

Mercer. 2015. : Trends and Driver of Workforce Turnover, The Result From Mercer's 2014 Turnover Survey, and Dealing With Unwanted Attrition. https://www.mercer.com/ content $/ \mathrm{dam} / \mathrm{mercer} /$ attachments/global/ webcasts/trends-and-drivers-of-workforceturnover-results-from-mercers-2014-turnover-survey.pdf Diakses pada tanggal 20 Juli 2016.

Mobley, William H. 1977. Intermediate Linkages in The Relationship Between Job Satisfaction and Employee Turnover. Journal of Applied Psychology, (62): 237-240. Sebab, Akibat dan Pengendaliannya. Terjemahan. Jakarta: PT Pustaka Binaman Press Indo.

Newstrom, John W. 2011. Organizational Behavior: Human Behavior at Work. New York: McGraw-Hill Education.

Noe. R., Hollenbck, J.R. Gerhart, B. Wright P.M. 2000. Human Resources Management. Edisi Ketiga. New York: McGraw Hill.

Rahman, Sahidur et al. 2008. Investigating the Reasons of Employee Turnover in Bangladesh: A Factor Analysis. The Chittagong University Journal of Business Administration. Vol. 23.

Rusdi, Muhammad et al. 2015. A Literature Review of Factor Causing Employee Turnover in Indonesian Banking. The International Journal of Business \& Management, 3 (5): 318-323.
Santoso, Singgih. 2012. Panduan Lengkap SPSS Versi 20. Jakarta: PT Elex Media Komputindo.

Sekaran, Uma dan Bougie, Roger. 2013. Research Methods for Business, Edisi Kelima. New York: Jhon Wiley \& Sons Ltd.

Sevilla, Consuelo G. et al. 2007. Research Methods. Quezon City: Rex Printing Company.

Sexton, Randall. S. et al. 2004. Employee Turnover: a Neural Network Solution. Computer \& Operation Research, (32): 26352651.

Shukla, SantriPT 2013. Employee Turnover in Banking Sector: Empirical Evidence. IOSR Journal of Humanities and Social Science, (11): 57-61.

Singarimbun, Masri \& Effendi, Sofian. 2009. Metode Penelitian Survey. Jakarta: LP3ES.

Suartana, I.W. 2000. Antenden dan Konsekuensi Job Insecurity dan Keinginan Berpindah pada Internal Auditor. Tesis S2. Universitas Gajah Mada.

Suwandi \& Indriantoro, N. 1999. Model Turnover Pasewark \& Strawser: Studi Empiris pada Lingkungan Akuntan Publik. Jurnal Riset Akuntansi Indonesia. (2): 173-195.

Towers Watson. 2013. 2012-2013 Global Talent Management and Rewards Study. 
Business and Finance Journal, Volume 3, No. 1, March 2018 